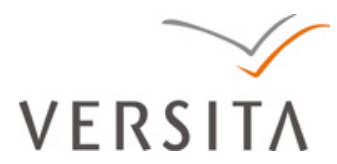

\title{
INVESTMENT PERFORMANCE OF HEDGE FUNDS
}

Waldemar Aspadarec, Ph.D.

Szczecin University

Faculty of Economics and Management

Department of Finance

Mickiewicza 64, 71-101 Szczecin, Poland

e-mail: goniag@poczta.fm

Received 10 April 2014, Accepted 18 November 2013

\begin{abstract}
Economic function of hedge funds is exactly the same as the one performed by investment funds. In both cases managers are in charge of investors' money. Investors hope that if they withdraw their money, they will recover their contribution and fair return. The first section of the article presents the essence of hedge funds. The second section discusses measures for assessing the effects of investment policy pursued by hedge funds. The third section analyses the investment performance of hedge funds compared to S\&P 500 index. The results of the analysis enabled the author to state that hedge funds achieve considerably higher rates of return regardless of market situation.
\end{abstract}

Keywords: hedge funds, financial market.

JEL classification: G15. 


\section{Introduction}

The majority of investment funds and all hedge funds are active funds, i.e. people investing in them confide that fund managers have skills that will contribute to delivering performance considerably better than in the case of passive funds or with other managers in charge. The article is aimed at analyzing and assessing the performance of hedge funds. Comprehensive analysis will be conducted with the use of Barclay Hedge Fund Index (compared with S\&P 500 Index). The first part of the article presents the essence of hedge funds and places a special emphasis on difficulties in defining this investment vehicle. Next section of the paper describes measures for assessing the effects of investment policy pursued by hedge funds. The last part of the article is devoted to investment performance of hedge funds. Time horizon covers the period from 1997 to 2011. Source materials used in the present paper were derived from Barclays Hedge.

\section{Essence of hedge fund}

According to conventional definition of hedge fund, it is a loosely regulated investment company. Its fees depend on its performance and it generally strives after achieving rates of return that are not closely correlated to rates of return on equity market or bond market. Due to the fact that the number of features typical of hedge funds is great, it is difficult to define what is not a hedge fund ${ }^{1}$. Since the very beginning of their activity, hedge funds have been hardly transparent in every respect. It was only at the end of 20th century that this information gap began to be bridged. This objective is to be accomplished by private companies that provide databases and specialize in collecting and processing information concerning the activity conducted by the funds under discussion. There is no statutory duty to disclose such data and therefore there is no single and complete database including information concerning the activity conducted by all the funds. Funds are free to deliver reports to databases and hence the vast majority of hedge funds report to one database.

The number of databases to which the funds under consideration report has been subject to increase along with the development of the sector. For instance, Liang has proven in his research that two databases contain only $30 \%$ of the same hedge funds. Furthermore, information they provide about the rates of return on these funds coincides in $47 \%$. Analyzing the value of assets under management, type of investment strategy and management expenses, only $53 \%$ of hedge funds included in the aforementioned databases revealed certain similarity ${ }^{2}$. 


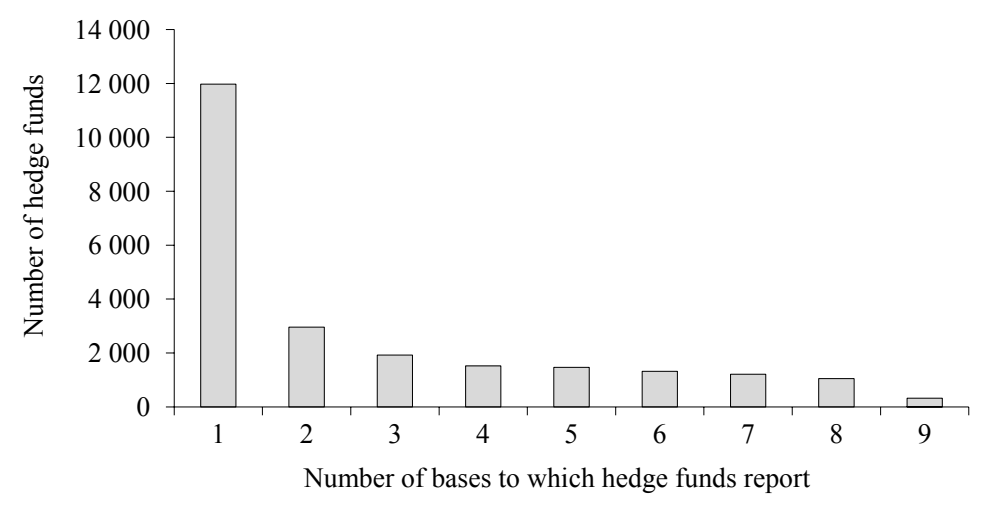

Fig. 1. Number of bases to which hedge funds report and number of hedge funds Source: own elaboration based on data derived from www.pertrac.com (15.02.2012).

One of the main commercial goods offered by professional database providers are hedge fund market indices. Generally speaking, indices are synthetic measures of change in certain units of value that make up the index ${ }^{3}$. Their main advantage is that they measure the efficiency of action. Indices are benchmark portfolios that enable one to perform comparative analysis within the sector of hedge funds as well as among different classes of assets. The advantages of indices are the same in the case of hedge fund industry and any other class of assets. In order to evaluate the activity of alternative funds, one may use the following ${ }^{4}$ :

- investment vehicle,

- non-investment vehicle.

Investment vehicles are to reflect the performance of hedge funds. They are classical index portfolio. They are construed on the basis of methodology used for developing traditional financial indices. They enable investors to invest in certain group of hedge funds in accordance with the assumed risk profile. They are not representative since they are construed on the basis of selected hedge funds that have agreed to provide reports. These indices are created from hedge fund units that are subject to publication because fund creators have agreed for greater transparency of their activity. Non-investment vehicles have representative character, are used for evaluating certain segments of hedge funds, and their calculation is based on information derived from databases created thanks to various criteria for the selection of funds and setting them up. Despite a large number of hedge fund vehicles that are published, only some of them enjoy good reputation and are adopted by investors. Barclay Hedge Fund Index, referred to in the present paper, is such a vehicle. As noticed by Kaiser and Haberfelner, during market 
turbulence investors should refrain from using indices for interpreting the performance of hedge funds ${ }^{5}$. Why? Because database sellers do not have full control over information provided by hedge funds, due to which hedge fund indices may not disclose honest information concerning the market.

Answers to the following questions are not obvious: is hedge fund performance better than investment fund performance or is single hedge fund performance better than the performance of the entire market?

First of all, evaluation is one of difficulties in calculating the rate of return. While it is not complex to determine the rate of return on classical funds investing in shares, hedge funds very often provide portfolio with financial instruments that are not subject to turnover on organized markets. The difficulty lies in the fact that closing price is not determined for instruments quoted on OTC market, hence hedge funds adopt theoretical models in order to evaluate the value of these instruments. Another solution used for eliminating this drawback is the evaluation of portfolio on the basis of quoted price and not transaction price, which may also give rise to controversy. One more difficulty lies in correct evaluation of rates of return on hedge funds. Honest evaluation has to include their adjustment to risk. Hedge funds may open both long and short positions, use derivatives and loan and therefore their exposition to market risk during a short period may be subject to change, which makes it difficult to evaluate the aforementioned exposition on the basis of limited sample of monthly rates of return. It should be borne in mind that techniques used effectively for estimating the exposition to risk in classical investment funds are not so effective with reference to hedge funds. The rate of return on equity fund are generally perceived as the return on share portfolio and several elements unique to a given fund. As far as hedge funds are concerned, the rate of return is best expressed as the rate of return on investment in derivative instruments.

As a result of extrapolating past performance into the future, the performance of a given fund may provide a selective view of the risk. This stems from following the strategy for payment profile similar to the one adopted by insurance enterprise selling earthquake insurance. While such an insurance does not normally require the enterprise to pay out compensation due to which its performance is good, if earthquake occurs the enterprise incurs massive losses that may exceed its profit cumulated during "peaceful" period. As for investors in insurance enterprises, they assess the risk of earthquake occurrence. However, investors in hedge funds are not able to do so since these funds face the risk of incurring serious losses before they materialize. Hedge fund taking such a risk will yield profit because "catastrophe" does not occur for a long time, which makes investors confident that the fund is not subject to change and is not exposed to 
market risk. Therefore, it may seem "good" as far as performance is concerned. The analysis of changeability may lead to conclusion that the fund is slightly changeable because investors evaluate the rates of return before unfavourable event takes place. Such reasoning justifies why this variability is not the best measure for assessing the risk taken by a given fund. This example proves that hedge fund may seem slightly changeable compared to investment fund. Nevertheless, people investing in the aforementioned fund face greater risk of losing all their assets ${ }^{6}$.

\section{Measures for assessing the effects of investment policy pursued by hedge funds}

Determining alpha coefficient is a method for assessing investment strategies in this sector. This part of the strategy is not accounted for by beta risk which stems from the exposition to market changes. The manager must be able to generate alpha and at the same time not to take beta risk. From statistical point of view, alpha is an absolute term in linear regression equation assessing the effective management of investment fund proposed by M.C. Jensen on the basis of $\mathrm{CAPM}^{7}$.

$$
\left(R_{t}-R_{f}\right)=\alpha_{t}+\beta_{t}\left(R_{m}-R_{f}\right)+e_{t}
$$

where:

$\alpha_{t}-\quad$ alpha coefficient,

$R_{t}-\quad$ rate of return on fund during the period under analysis,

$R_{f}-\quad$ risk-free rate of return during the period under analysis,

$B_{t}-\quad$ beta coefficient for the fund during the period under analysis,

$R_{m}-\quad$ rate of return on market portfolio during the period under analysis,

After transformation the following formula can be applied:

$$
\alpha_{t}=\left(R_{t}-R_{f}\right)-\beta_{t}\left(R_{m}-R_{f}\right)-e_{t}
$$

Jensen's alpha is an excess and risk-weighted rate of return. The higher the rate, the better the performance of a given hedge fund. Positive rate implies that the fund is managed above the average, whereas negative rate indicates that portfolio performance is worse than excess market rate $\left(R_{m}-R_{f}\right)$ which equals zero (implying that the market is neutral) ${ }^{8}$.

The analysis of non-regulated funds is based on the assumption that once all fees have been taken into account their alpha is non-negative. This implies that hedge fund managers' earnings are sufficient to cover fees they have imposed. Analyzing the alpha, academic community pays 
attention to the following two issues: average value of alpha and period during which alpha is found in particular funds. In 2005, Ibbotson and Chen analysed the performance of hedge funds during the period 1999-2004. It turned out that average rate of return on each fund amounted to 9.1\% after taking fees into account. Rate of return free of charge is divided into two components. The first one is profit generated thanks to being exposed to broad market - "beta risk". This exposition generated risk amounting to $5.4 \%$, which implies that average alpha reached $3.7 \%$. The analysis suggests that alpha in hedge funds is considerably higher than in investment funds committing their financial resources in shares during the aforementioned period ${ }^{9}$.

In 2006, Fung, Hsieh, Naik and Ramadorai conducted the analysis of hedge funds. It has turned out that in fact there are two groups of funds. About $20 \%$ of funds are managed by people with useful skills reflected in positive and high alpha, whereas the remaining ones do not generate definitely positive alpha ${ }^{10}$.

Research conducted by Jagannathan, Malakhov and Novikov in 2006 provides an answer to the question about hedge fund managers' capability of maintaining alpha over time. It suggests that the funds under consideration are able to maintain only $50 \%$ of their good performance during a three-year period, which implies that if the alpha for a given fund is $2 \%$ during such a period, one may expect that the alpha will amount to $1 \%$ during another three-year period $^{11}$. Summing up, a great number of studies confirm that there is a high percentage of funds with largely positive alpha, which indicates that the ability to select good hedge fund may be extremely profitable. It should also be borne in mind that extrapolating past performance into the future may be risky. However, there are studies confirming that former performance of funds is useful in choosing the good ones in the future.

In order to measure average investment performance of hedge funds (i.e. hedge fund index), one should analyse certain number of funds for the sake of statistical reliability (so that the performance of one fund does not affect the performance as such). That is why Barclay Hedge has been calculating indices only since 1997, although it has been operating for 25 years.

\section{The analysis of hedge fund performance during the period 1997-2012}

The major goal of this section is to examine the performance of hedge funds in order to see if this performance is better than the one of investment funds. It is not easy to answer the above question. Investing in hedge funds, whose aim is to achieve an unlimited rate of return, in fact consists in ,placing an emphasis” on managerial skills. As a result, managers of hedge funds are faced with serious risk. 


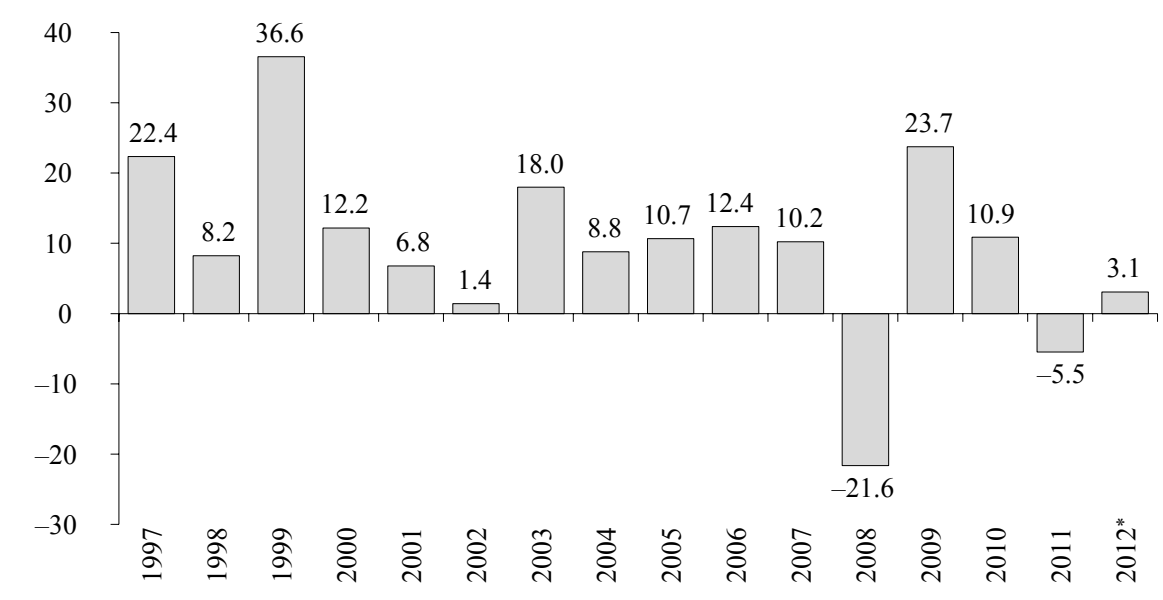

* -2 Q 2012.

Fig. 2. Rates of return on hedge funds during the period 1997-2012 (\%)

Source: own elaboration based on www.barclayhedge.com (15.07.2012).

Figure 2 shows that the vast majority of hedge funds perform their function, i.e. generate as high absolute profit (and not relative to benchmark) as possible. Even the difficult year 2000 (dotcom bust) did not prevent hedge funds from being profitable, admittedly to some extent, yet it seems that investors met their main need, i.e. earned or did not lose at worst. What is more important, when the situation on the market was stable, i.e. both during market growth and market stagnation hedge funds generated substantial absolute profit (over 36\% in 1999, i.e. during the time of technological boom).

Years 2008 and 2011 were alarming exceptions. The main reason behind losses incurred in 2008 was not market downturn or considerable changeability of markets. After all, hedge funds like changeability, particularly those managed aggressively and capable of changing their short position into long one and vice versa dynamically. The reason behind that state of affairs was probably market illiquidity, i.e. situation when fund manager knows at which prices to open, close or invert positions, however the market does not always enable him/her to complete a transaction. Other reasons were problems with loan servicing and panic among the clients of funds that did not use closed periods. Funds may have to close a given position at the least perfect moment and face problems with institutions that service them or are superior to them. Nevertheless, it is worth mentioning that in 2011 and to be more precise in "bust" August average loss in the industry amounted to over $3 \%$, which seems a slight loss taken account of 
scale and suddenness of stock market crash and the fact that hedge funds are labelled aggressive institutions. Let us look at hedge fund performance in comparison with the stock market.

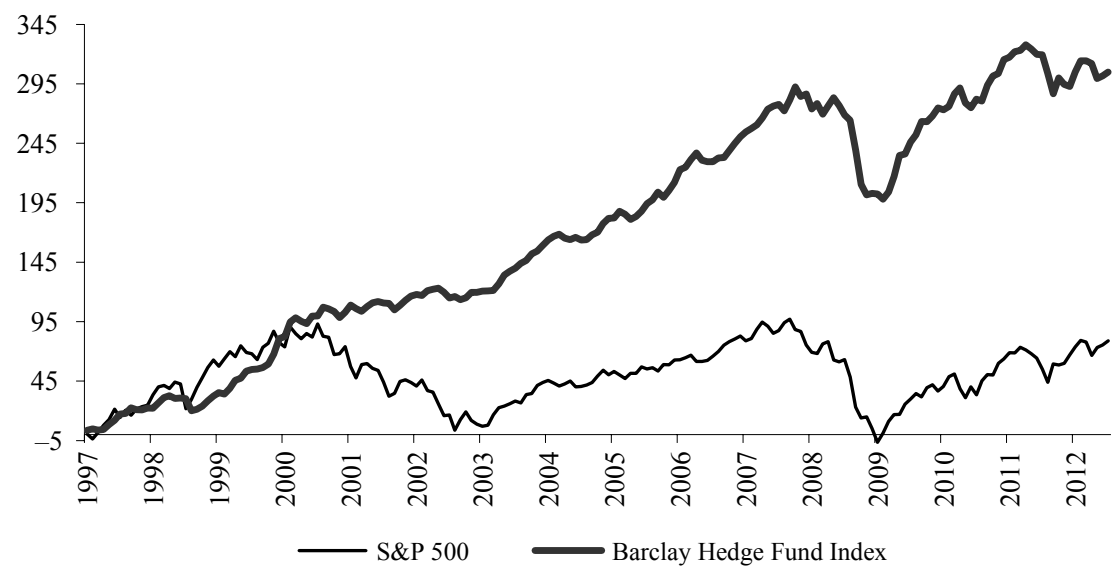

Fig. 3. Barclay Hedge Fund Index against S\&P 500 Index during the period 1997-2012 (\%) Source: own elaboration based on data derived from: www.barclayhedge.com and stooq.pl (15.07.2012).

Figure 3 shows that an investor who committed his/her resources in the aforementioned funds during the period 1997-2007, i.e. when global financial crisis arose, reached the rate of return amounting to $286.4 \%$ (free of all additional fees such as management bonus) or effective annual rate of return amounting to circa $14.4 \%$. The overall performance of investment funds actively managed on the stock market is not better than the performance of stock market taken account of all the fees. Therefore, hedge funds will be better than actively managed investment funds unless their performance is better than the performance of the stock market as a whole. A hypothetical investor who committed his/her financial resources in Standard \& Poor's 500 Index would earn $75.3 \%$ during the analogical period, i.e. effective annual rate of return amounting to $5.7 \%$. The flexibility of hedge funds and its advantages could be noticed in January 2009 when the rate of return for a hypothetical investor (who committed his/her financial resources in hedge funds at the beginning of 1997 ) reached $202.4 \%$. This rate amounted to $-6.4 \%$ in the case of S\&P 500. The performance of classical investment funds, stemming from the lack of mobility, "deprived" many investors of confidence that long-term investment, i.e. in line with "buy and hold" principle, is effective. In 2009 global financial markets reported minimums. Since then the situation on financial markets has improved significantly unlike the situation of 
real economy. This proves that financial markets have lost touch with the real economy since central banks (mainly FED and ECB) printed money on a large scale.

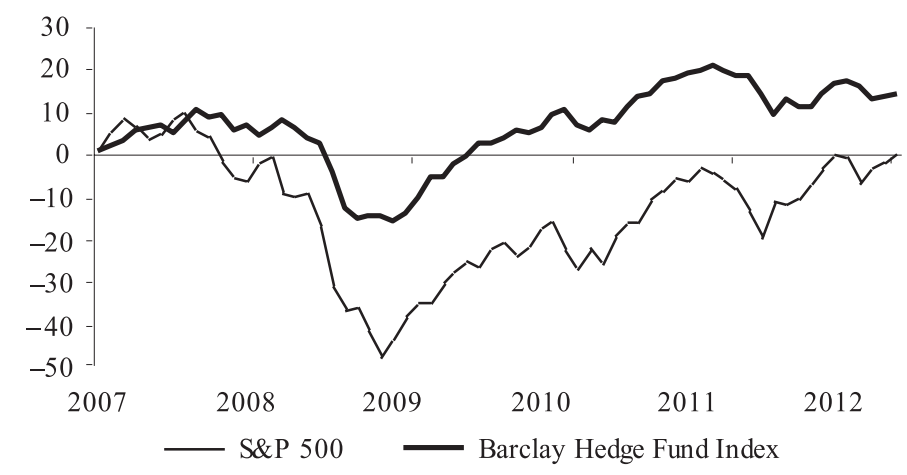

Fig. 4. Barclay Hedge Fund Index against S\&P 500 Index during the period 2007-2012 (\%) Source: own elaboration based on data derived from: www.barclayhedge.com and stooq.pl (15.07.2012).

Summing up, at the end of the first quarter of 2012, i.e. after 16.5 years of investing, the performance of the investor's hedge fund portfolio reflected in Barclay Hedge Fund Index amounted to $301.8 \%$ and was significantly higher than the rate of return on S\&P 500 Index which reached $75.4 \%$. During the entire period under analysis, the overall performance of investment hedge funds was always positive, namely from $1.42 \%$ in 2002 to $36.56 \%$ in 1999 . The years 2008 and 2011 were exceptions to the rule. Global financial crisis emerged in 2008 and showed that even such flexible investment vehicles as hedge funds, and to be more precise the entire industry, did not manage to reach positive rate of return. For the second time in history negative rate of return (amounting to $-5.48 \%$ ) was reported in 2011. During the entire period under consideration, the performance of hedge funds was correlated with opportunities offered by particular segments of global financial market. In 2008 drop in Barclay Hedge Fund Index stemmed from the structure of hedge funds dominated by net equity exposure to equity long bias and managed futures. Market breakdown in 2008 was characterized by parallel and significant downturn on capital markets and raw material markets.

While research enables one to verify hedge fund returns with the use of Jensen alpha, persons directly responsible for investing financial resources (based on information derived from professional databases) determine rates of return on the basis of classical Sharpe ratio or its variations. Table 1 presents hedge fund returns depending on investment strategies the funds followed throughout the period under analysis. 
Table 1. Rates of return on subindexes of hedge funds between 1997 and June 2012

\begin{tabular}{|l|c|c|}
\hline $\begin{array}{c}\text { Subindexes of strategies followed } \\
\text { by hedge funds }\end{array}$ & $\begin{array}{c}\text { Average annual rate of return } \\
(\%)\end{array}$ & Sharpe Ratio \\
\hline Convertible Arbitrage & 7.51 & 0.64 \\
\hline Dedicated Short Bias & -4.07 & -0.42 \\
\hline Emerging Markets & 7.28 & 0.28 \\
\hline Equity Market Neutral & 4.84 & 0.17 \\
\hline Event Driven & 9.17 & 0.97 \\
\hline Distressed Securities & 10.21 & 1.08 \\
\hline Multi-Strategy & 8.65 & 0.82 \\
\hline Risk Arbitrage & 6.52 & 0.83 \\
\hline Fixed Income & 5.44 & 0.42 \\
\hline Global Macro & 11.83 & 0.91 \\
\hline Equity Long/Short & 9.09 & 0.61 \\
\hline Managed Futures & 5.87 & 0.24 \\
\hline Multi-Strategy & 7.97 & 0.91 \\
\hline
\end{tabular}

Source: own elaboration based on data derived from www.hedgeindex.com (15.07.2012).

The analysis of hedge fund performance between 1994 and October 2012 suggests that apart from one sub-index describing the strategy followed by hedge funds, i.e. Dedicated Short Bias which amounted to $-4.07 \%$, all sub-indexes were positive. Both in 2008 and 2011 the entire sector of hedge funds recorded negative rates of return on exposure to equity short bias. The rates in question generated $40.91 \%$ and $6.64 \%$ of profit respectively.

Furthermore, it should be stated that hedge fund market could develop because these funds have become an instrument for portfolio diversification. They may use derivatives without any limitations and via short sale they strive after reaching indefinite rate of return due to which they are slightly or negatively correlated with traditional financial instruments. The analysis of correlation between Barclay Hedge Fund Index and global stock market measured with the use of S\&P 500 Index during the period 2000-2011 suggests that hedge funds were hardly correlated with global stock market throughout the period 2000-2003. Afterwards, i.e. before global financial crisis, correlation became significant and then weakened again. The index under discussion reached 0.24 during the period 2000-2003, 0.62 from 2003 to 2007 and 0.45 throughout the period 2007-2011 12 Thesis can be formulated that slight correlation between hedge funds and stock market is one of major reasons behind the inflow of capital from institutional investors to hedge funds. Slight correlation after the crisis indicates that hedge funds have moved the centre of gravity from capital market to commodities market. To be more 
precise, they have moved certain resources treated as investors' response to policy pursued by central banks printing money on an unprecedented scale.

\section{Conclusions}

Summing up, it can be stated that since hedge funds place a considerable emphasis on seeking arbitrage opportunities, they are interested mainly in producing absolute profit, and not exceeding benchmark such as indices on stock market or bond market. This makes them neutral in market terms. Hedge funds are expected to deliver positive performance regardless of market performance. Taken the above into account, it is not unusual that funds under discussion did not cope well when American stock market reported serious losses. Such a situation was observed at the beginning of 21 st century, i.e. when dotcom bubble burst. It should be borne in mind that many investors tend to extrapolate their past performance into the future due to the fact that the performance of hedge funds was so remarkable compared to stock market. Furthermore, shareowners may consider hedge funds an attractive vehicle for diversification. During last few years the correlation between the performance of these funds and rates of return on global capital markets became significant. Therefore, benefits accruing from diversification are not obvious any more. In fact some hedge funds have become classical investment funds. This stems from a situation when an investor pays certain amount for management and performance typical of hedge funds as well as for risk and rates of return typical of classical investment funds. Generally speaking, thanks to active management and flexible investment policy hedge funds are more profitable than classical investment funds.

\section{Notes}

1 McCrary (2005).

2 Liang (2000).

3 Wiśniewska (2007).

${ }^{4}$ Niedziółka (2009).

5 Kaiser, Haberfelner (2011).

6 Stulz (2007).

7 Jensen (1968).

8 Bodie, Kane, Marcus (2008).

9 Ibbotson, Chen (2005).

${ }^{10}$ Fung, Hsieh, Naik, Ramadorai (2007).

11 Jagannathan, Malakhov, Novikov (2006).

12 Own elaboration based on data derived from www.barclayhedge.com, Bloomberg. 


\section{References}

Bodie, Z., Kane, A. \& Marcus, A.J. (2008). Investments. New York: McGraw-Hill.

Fung, W. \& Hsieh, D.A. (2002). Hedge-Fund Benchmarks: Information Content and Biases. Financial Analysis Journal, Vol. 58, No. 1.

Ibbotson, R.G. \& Chen, P. (2005). Sources of Hedge Fund Returns: Alphas, Betas, and Costs. Yale ICF (International Center for Finance) Working Paper 05-17, Yale University, New Haven, $\mathrm{CN}$.

Jagannathan, R., Malakhov, A. \& Novikov, D. (2006). Do Hot Hands Persist Among Hedge

Fund Managers? An Empirical Evaluation. National Bureau of Economic Research Working Paper W12015.

Jensen, M.C. (1968). The performance of mutual funds in the period 1945-1964. Journal of Finance, Vol. 23, No. 2.

Kaiser, D.G. \& Haberfelner, F. (2011). Hedge fund biases after the financial crisis. Center for Practical Quantitative Finance, Frankfurt School of Finance and Management 2011, Working Paper, http://papers.ssrn.com/sol3/papers.cfm?abstract_id=1809570 (15.02.2012).

Lhabitant, F-S. (2007). Handbook of Hedge Funds. Hoboken.

Liang, B. (2000). Hedge funds: the living and the dead. Journal of Financial and Quantitative Analysis, Vol. 35, No. 3.

McCrary, S.A. (2005). Hedge Fund Course. New York: John Wiley \& Sons.

Niedziółka, P. (2009). Fundusze hedgingowe a stabilność finansowa. Warszawa: Difin.

Perez, K. (2011). Fundusze Hedge. Istota, strategie, potencjat rynku. Warszawa: C.H. Beck.

Perez, K. (2011). Wyniki inwestycyjne funduszy hedge. Czynniki wpływające ich interpretacje. Bank i Kredyt, Vol. 42, No. 6.

Stulz, R.M. (2007). Hege funds: past, present, future. Journal of Economic Perspectives, Vol. 21, No. 2.

Wiśniewska, E. (2007). Giełdowe instrumenty pochodne. Toruń: Wydawnictwa Naukowe UMK. 